Sains Malaysiana 50(3)(2021): 779-790

http://dx.doi.org/10.17576/jsm-2021-5003-19

\title{
Anorectic Effect, Biochemical and Hematological Profiles of Alkaloid Extract from Mitragyna speciosa Korth. in Rats
}

(Kesan Anorektik, Profil Biokimia dan Hematologi Ekstrak Alkaloid daripada Mitragyna speciosa Korth. dalam Tikus)

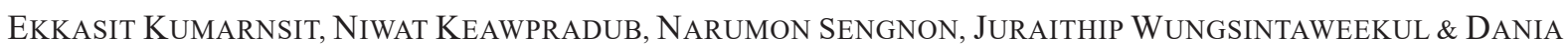 \\ CHEAHA*
}

\section{ABSTRACT}

There is an on-going debate about medicinal use of kratom plant (Mitragyna speciosa (MS)) on whether it has beneficial or adverse effects. This study aimed to examine long-term weight-reducing effects, toxicity, and dopamine pathway activation of MS alkaloid extract on adult male Wistar rats. In anorexic study, the rats were divided into 3 groups (n = 10), receiving intragastric administration once a day for 19 weeks as control (distilled water), chronic (20 mg/kg MS alkaloid extract) and withdrawal (20 mg/kg MS alkaloid extract for week 1-12 and distilled water for week 13-19) groups. Body weights were measured daily, and blood samples were collected at the end of study for biochemical and hematological tests. In immunohistochemistry, the effects of the extract (40 and $80 \mathrm{mg} / \mathrm{kg}$ ) on the nucleus accumbens (NAc) and striatum (STr) were determined by using Fos-like immunoreactivity. From week 2 to 19, the results showed a significant reduction in body weight gain produced by the extract. Cessation of the treatment at week 12 did not result in a rebound weight gain. Chronic MS alkaloid extract treatment significantly decreased non-fasting blood sugar, triglyceride, uric acid and blood urea nitrogen (BUN). However, elevated SGOT may suggest possible hepatotoxicity. Chronic MS alkaloid extract treatment also produced baseline levels for most of the hematological parameters except a decrease of monocyte. In immunohistochemistry, the acute treatment did not induce Fos-like immunoreactivity in the NAc and STr. These data demonstrated the beneficial effects of the MS alkaloid extract for possible treatment of metabolic syndromes without toxicity and rewarding effect.

Keywords: Addiction; anorectic; kratom; Mitragyna speciosa; toxicity

\section{ABSTRAK}

Terdapat perbahasan berterusan mengenai penggunaan tanaman kratom (Mitragyna speciosa (MS)) sebagai ubat, sama ada ia memberikan kesan yang baik atau buruk. Kajian ini bertujuan untuk mengkaji kesan pengurangan berat badan jangka panjang, ketoksikan dan pengaktifan jalur dopamin ekstrak alkaloid MS pada tikus Wistar jantan dewasa. Dalam kajian anoreksik, tikus dibahagikan kepada 3 kumpulan $(n=10)$, iaitu kumpulan kawalan yang menerima pemberian intragastrik sekali sehari selama 19 minggu sebagai kawalan (air suling), kumpulan kronik (20 mg/kg MS alkaloid ekstrak) dan kumpulan penarikan (20 mg/kg ekstrak alkaloid MS untuk minggu 1-12 dan air suling untuk minggu 13-19). Berat badan diukur setiap hari dan sampel darah dikumpulkan pada akhir kajian untuk ujian biokimia dan hematologi. Dalam keimunan-histokimia, kesan ekstrak (40 dan $80 \mathrm{mg} / \mathrm{kg}$ ) pada nukleus akumbens (NAc) dan striatum (STr) ditentukan dengan menggunakan reaktiviti imun mirip-Fos. Dari minggu 2 hingga 19, terdapat penurunan ketara dalam kenaikan berat badan yang dihasilkan oleh ekstrak tersebut. Penghentian rawatan pada minggu ke-12 tidak menyebabkan kenaikan berat badan. Rawatan ekstrak alkaloid MS kronik menurunkan gula darah tanpa puasa, trigliserida, asid urik dan nitrogen urea darah (BUN). Walau bagaimanapun, kenaikan SGOT mungkin menunjukkan kemungkinan kehepatotoksidan. Rawatan ekstrak alkaloid MS kronik juga menghasilkan tahap garis dasar bagi kebanyakan parameter hematologi kecuali penurunan monosit. Dalam keimunan-histokimia, rawatan akut tidak menyebabkan reaktiviti imun mirip-Fos pada NAc dan STr. Data ini menunjukkan kesan yang baik daripada ekstrak alkaloid MS untuk kemungkinan rawatan sindrom metabolik tanpa ketoksikan dan kesan ganjaran.

Kata kunci: Anorektik; ketagihan; ketoksikan; kratom; Mitragyna speciosa 


\section{INTRODUCTION}

The proportion of obese people is steadily increasing along with progressively increased health concerns such as diabetes, heart diseases, and hypertension (Ding \& Mak 2015; Gallagher et al. 2010). Many classes of drugs are used for obesity treatment. Some selective serotonin reuptake inhibitors (SSRIs) that act as antidepressants were also found to reduce food intake and induce weight loss (Bitsch \& Skrumsager 1987; McElroy et al. 2003). These drugs increase extracellular serotonin levels in the CNS. However, long-term use of some SSRIs caused weight gain (Sussman et al. 2001). In addition, the mental and physical side effects of some SSRIs have been consistently evidenced such as decreased sexual functioning (Ahrold \& Meston 2009) or induced hallucinations and delusions (Capaldi \& Carr 2010).

Mitragyna speciosa (MS), called 'kratom' in Thailand, is a member of the Rubiacaea plant family. It has been used as a medicinal plant for centuries (Jansen \& Prast 1988). Natural MS alkaloids appeared to contain several alkaloid components including mitragynine $(0.33 \%)$, speciogynine $(0.033 \%)$, paynantheine $(0.043 \%)$ and other alkaloids (abundance less than $0.005 \%$ ) (Ponglux et al. 1994). Mitragynine is a major indole alkaloid of MS shown to have an antinociceptive action. However, 7-hydroxymitragynine, a minor constituent of this plant, also exhibited an even higher antinociceptive potency than that of mitragynine both in vitro (Takayama et al. 2002) and in vivo (Matsumoto et al. 2004). Moreover, other constituent alkaloids of the plant may also exert potent therapeutic effects.

In terms of application as a medicinal product, MS has been widely investigated for its therapeutic and toxic effects. Apart from the antinociceptive action, anorectic and hypoglycemic activities are two main properties that have been intensively focused upon. Previously, alkaloid extract from MS was found to decrease food intake and reduce body weight in normal rats (Kumarnsit et al. 2006). This finding suggested the efficacy of kratom as an alternative medicine for obesity treatment. Basically, withdrawal from habitual use of drugs such as tobacco, alcohol, cannabis, amphetamines, and cocaine, is followed by overeating which is an undesired outcome of rehabilitation (Edge \& Gold 2012). In addition, the aqueous extract of this plant was demonstrated to attenuate ethanol withdrawal symptoms in animals (Kumarnsit et al. 2006). However, further evaluation of long-term toxicity is needed in clinical levels. In particular, the addictive properties of kratom and other undesirable effects remained to be determined.

Recently, many concerns were raised by research findings of pure mitragynine regarding its possible addictive property (Harun et al. 2015; Sufka et al. 2014;
Yusoff et al. 2016). In conditioned place preference test, mitragynine effect was comparable to that of $\mathrm{S}(+)$ amphetamine in rats (Sufka et al. 2014). Moreover, acute and prolonged treatments (28 days) of mitragynine were demonstrated to have adverse effects on motor functions, learning and memory processes (Apryani et al. 2010). Particularly, the toxicity of mitragynine was confirmed by liver, kidney, and brain histopathological changes, as well as hematological and biochemical changes following 28 days treatment (Sabetghadam et al. 2013). In contrast to pure mitragynine, the use of crude MS alkaloid extract has demonstrated many beneficial properties (Cheaha et al. 2015; Farah Idayu et al. 2011; Kumarnsit et al. 2007). Therefore, crude alkaloid extract of this plant was chosen for the investigation as a possible safer fraction for further applications.

In general, addictive drugs such as amphetamine and cocaine are known to modulate dopamine release and uptake mechanism (Pifl et al. 1995; Sharp et al. 1987). This results in increasing extracellular dopamine in various brain areas. Particularly, this action of amphetamine was found in the NAc (nucleus accumbens) and STr (striatum) (Seiden et al. 1993). These two brain regions are terminal areas of the mesolimbic and nigrostriatal dopamine pathways, respectively. Repetitive activation of the NAc and STr by psychostimulants and opiates through dopaminergic action is believed to establish drug dependence (Hyman 1996). Activation of dopamine receptors in these areas increases cellular activity including gene expression via a variety of intracellular mechanisms. The expression of immediate early gene c-fos is of particular interest, especially as a result of activation by addictive drugs. Fos, a protein product of c-fos gene expression, can be induced by amphetamine (Graybiel et al. 1990). Therefore, Fos expression in the NAc and STr induced by psychostimulants and opiates has been consistently demonstrated (Ruksee et al. 2008).

In previous studies, crude alkaloid extract from MS significantly produced anorectic effects in rats following both acute and long-term treatments (Kumarnsit et al. 2006). Therefore, the present study used the MS alkaloid extract to investigate its possible rebound effect on body weight, biochemical and hematological profiles, and stimulatory effect on the dopaminergic brain regions in a rat model.

\section{MATERIALS AND METHODS}

PLANT MATERIALS AND EXTRACTION

Young leaves of MS were collected from natural sources in Songkhla and Satun provinces, Thailand during 2004-2005. Authentication of the plant material was carried out at the Department of Pharmacognosy 
and Pharmaceutical Botany, Faculty of Pharmaceutical Sciences, Prince of Songkla University, Thailand where the herbarium voucher specimens (no. PCOG/MS001-002) have been deposited.

Extraction and isolation of the MS alkaloid extract were described in a previous study (Harizal et al. 2010). The major alkaloid, isolated by silica-gel column chromatography eluting with $\mathrm{MeOH}: \mathrm{CHCl}_{3}$ (5:95), was identified as mitragynine with the standard spectroscopic methods (MS, ${ }^{1} \mathrm{H}$ NMR, and ${ }^{13} \mathrm{C}$ NMR). HPLC analysis for quantification of MS alkaloids including mitragynine, paynantheine, and speciogynine was performed as described previously (Harizal et al. 2010; Ponglux et al. 1994). HPLC system equipped with HPLC SHIMADZU LC2030 3D was used. Column was VertiSepTM USP C18 HPLC Column, $4.6 \times 250 \mathrm{~mm}, 5 \mu \mathrm{m}$. The column was isocratically eluted with $20 \mathrm{mM}$ ammonium acetate $(\mathrm{pH}$ 6): acetonitrile; 35:65 (\% v/v). The flow rate was $1 \mathrm{~mL} /$ min. Injection volume was $20 \mu \mathrm{L}$ and a UV detector was set at $225 \mathrm{~nm}$. Amount of each alkaloid was expressed as $\mathrm{mg} / \mathrm{g}$ of the alkaloid extract.

Prior to animal treatment, the solution of the MS alkaloid extract was prepared by dissolving the extract in co-solvent (tween 80: propylene glycol: $\mathrm{H}_{2} \mathrm{O}$ at a 1:4:4 ratio) and adjusted to desired concentrations with distilled water.

\section{ANIMALS}

Male Wistar rats weighing 180-200 g at the start of the experiment were used. They were individually housed in wire-mesh cages $(20 \times 25 \times 35 \mathrm{~cm})$ with standard environmental conditions and fed with standard commercial food pellets and water ad libitum. Animals were acclimatized to this condition for at least one week prior to the experiment, provided they showed relatively stable food consumption. The protocols for care and use of experimental animals described in the present study were approved and guided by the Animals Ethical Committee of the Prince of Songkla University (MOE 0521.11/613).

\section{MEASUREMENT OF ANIMAL'S BODY WEIGHTS}

Rats were divided into 3 groups $(\mathrm{N}=10)$, a control group and 2 treatment groups (chronic and withdrawal groups). By using ball-tipped gavage needle attached to a syringe, they received intragastric administration of either distilled water or a dose of MS alkaloid extract (20 mg/ $\mathrm{kg}$ ) at 6:00 p.m. daily for 19 consecutive weeks. The control group was fed with distilled water for the whole experiment. The chronic group was given MS alkaloid extract for 19 weeks while the withdrawal group received MS alkaloid extract for the first 12 weeks, followed with 7 weeks of distilled water. During the experimental period, they could access food and water ad libitum. Body weights of animals were measured once a day throughout the experiment.

\section{BLOOD BIOCHEMICAL AND HEMATOLOGICAL TESTS}

On the final day, whole blood samples were collected through cardiac puncture. Each sample was transferred to a glass tube and mixed well with K3 EDTA and sodium fluoride as an anticoagulant and a glycolytic inhibitor, respectively. Therefore, blood biochemical parameters including non-fasting blood sugar, total cholesterol, triglyceride, uric acid, BUN, creatinine, total protein, albumin, total bilirubin, direct bilirubin, SGOT (serum glutamic oxaloacetic transaminase), SGPT (serum glutamic pyruvic transaminase), alkaline phosphatase, sodium and potassium were analyzed using Roche Cobas Mira S Chemistry Analyzer in the Central Laboratory (Hatyai, Songkhla, Thailand). Hematology was promptly conducted with an automatic analyzer. Morphology of blood cells was also thoroughly investigated by visual inspection for atypical lymphocyte, anisocytosis, hypochromia, microcyte, poikilocytosis, ovalocytosis and platelet on smear. Values of these parameters were immediately measured using Abbott Cell-Dyn CD-1800 Hematology Analyzer in the same laboratory to the blood biochemical test.

\section{IMMUNOHISTOCHEMISTRY FOR FOS DETECTION IN THE BRAIN REGIONS OF DOPAMINE PATHWAYS}

Animals were divided into a control group to receive saline and two treated groups to receive either 40 or $80 \mathrm{mg} / \mathrm{kg}$ of the MS alkaloid extract through intraperitoneal injection (i.p.). Morphine ( $5 \mathrm{mg} / \mathrm{kg}$ ) was used as a positive control. All administrations were made between 9:00-9:15 a.m. To humanely terminate the animals, $2 \mathrm{~h}$ and $30 \mathrm{~min}$ after treatment, the rats were deeply anesthetized with sodium pentobarbitone $(40 \mathrm{mg} / \mathrm{kg})$. By itself, this anesthetic does not have a strong inducing effect on Fos expression in rat brains (Takayama et al. 1994). Animals were then perfused with fixative solution containing 4\% paraformaldehyde in $0.1 \mathrm{M}$ phosphate buffer (PB) $\mathrm{pH}$ 7.4. Brains were removed and post-fixed overnight in the same fixative solution at 4 ${ }^{\circ} \mathrm{C}$. They were then transferred to sucrose solution $(30 \%$ sucrose in $0.1 \mathrm{M} \mathrm{PB}$ ) for cryoprotection until they sank Brains were frozen and stored at $-70{ }^{\circ} \mathrm{C}$ until the process for detection and localization of Fos protein.

Coronal sections $(40 \mu \mathrm{m})$ were cut through the forebrain with a cryostat between $2.20 \mathrm{~mm}$ and 0.70 $\mathrm{mm}$ anterior to the bregma. The rat brain atlas was used for confirmation of the NAc and STr brain areas. 
The free-floating sections were incubated with anti-Fos antibodies raised in sheep (Chemicon, CA, USA) diluted 1: 100 in PBT (PB containing 5\% normal donkey serum and $0.3 \%$ TritonX100 overnight at $4{ }^{\circ} \mathrm{C}$ and washed $3 \times 15$ min with PB. They were then incubated with fluorescein isothiocyanate (FITC)-conjugated anti-sheep immunoglobulin antibodies (Chemicon, CA, USA) for 2 $\mathrm{h}$ at room temperature and washed 3 times $15 \mathrm{~min}$ with $\mathrm{PB}$. Sections were mounted on glass slides. Images were captured with an Olympus DP-50 digital camera and image files were processed using Microimage software (Olympus).

Controls for non-specific staining were performed in which primary antibody was omitted. The images were viewed with a PC computer using the Adobe Photoshop 7.0 program. Sections were coded with random numbers to prevent bias in quantification. Foslike immunoreactive nuclei were counted in the NAc and STr. At least 10 separate brain sections from each rat were used for quantification. The numbers of Foslike immunoreactive cells per section were counted bilaterally and averaged for each rat.

\section{STATISTICAL ANALYSIS}

Body weights of animals were measured once a day and the values of the final day in each week were chosen to represent as the body weight of that week. All values of body weight, hematological, blood biochemical parameters and numbers of Fos-like immunoreactive cells of each group were presented as mean \pm SEM. Statistical differences between the control and the MS alkaloid extract-treated groups were determined by using one-way analysis of variance followed by Tukey method for body weight and Fos detection and Student's t-test for hematological and blood biochemical tests. Significant level with $P<0.05$ was used for all statistical analyses.

\section{RESULTS}

\section{CHARACTERISTIC OF MS ALKALOID EXTRACT}

The MS alkaloid extract appeared as a dark brown mass. Determination of the alkaloids in the extract by HPLC showed the presence of mitragynine $47.1 \mathrm{mg} / \mathrm{g}$, paynantheine $8.4 \mathrm{mg} / \mathrm{g}$ and speciogynine $2.2 \mathrm{mg} / \mathrm{g}$, which accounted for 82,14 , and $4 \%$ of the total alkaloids respectively, as shown in Figure 1.

\section{mAU}

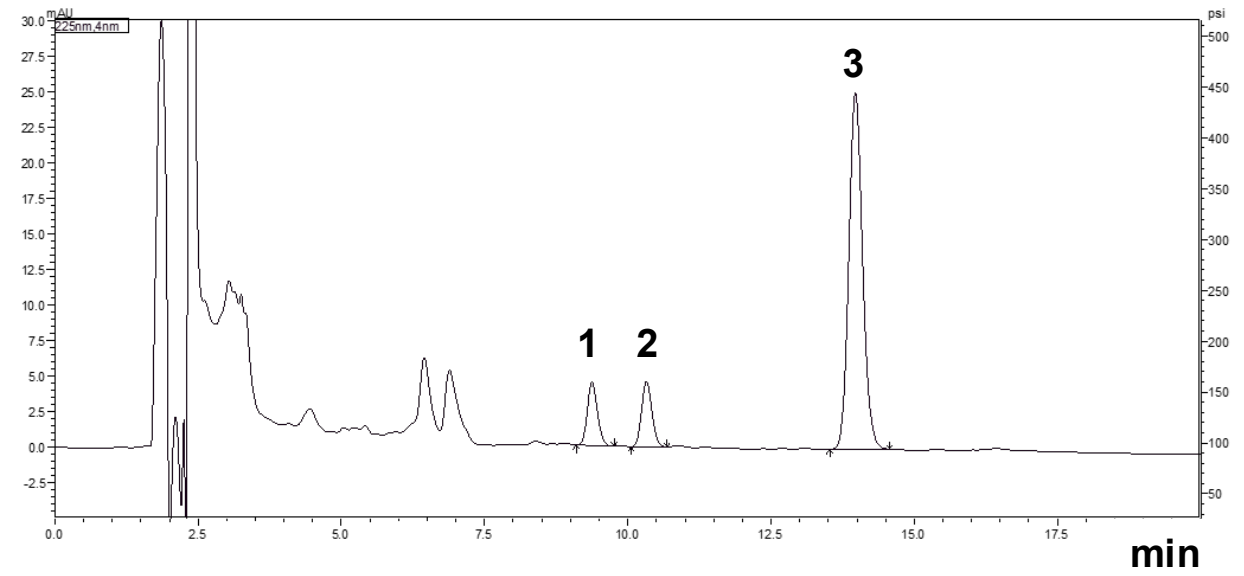

FIGURE 1. HPLC chromatogram of the MS alkaloid extract. 1: speciogynine at $9.3 \mathrm{~min}$; 2: paynantheine at $10.3 \mathrm{~min} ; 3$ : mitragynine at $13.9 \mathrm{~min}$

\section{EFFECT OF CHRONIC ADMINISTRATION AND WITHDRAWAL OF MS ALKALOID EXTRACT ON BODY WEIGHT}

During the experiment, none of the rats perished, nor was there obvious change of behavior recorded in any group except the decreases of feeding behavior. The effect of chronic administration of the MS alkaloid extract on body weight was analyzed (Figure 2). One-way ANOVA showed significant effects of either chronic or withdrawal of MS alkaloid extract treatment $(p<0.001)$. Treated animals exhibited significantly lower body weights than control 
levels. Significant differences between control and MS alkaloid extract treated groups were detected from the 2nd to the final week. The difference was progressively obvious by time. After a 19-week treatment, both chronic and withdrawal groups equally reduced body weight gain in comparison to control group. Their body weights were about $360 \mathrm{~g}$ compared to $400 \mathrm{~g}$ of control animals. In the withdrawal group after the MS alkaloid extract was withdrawn, no rebound weight gain was found during the MS alkaloid extract-free period. Their body weights did not return to control levels. In fact, the MS alkaloid extract withdrawal animals had about the same weight as the chronic animals.

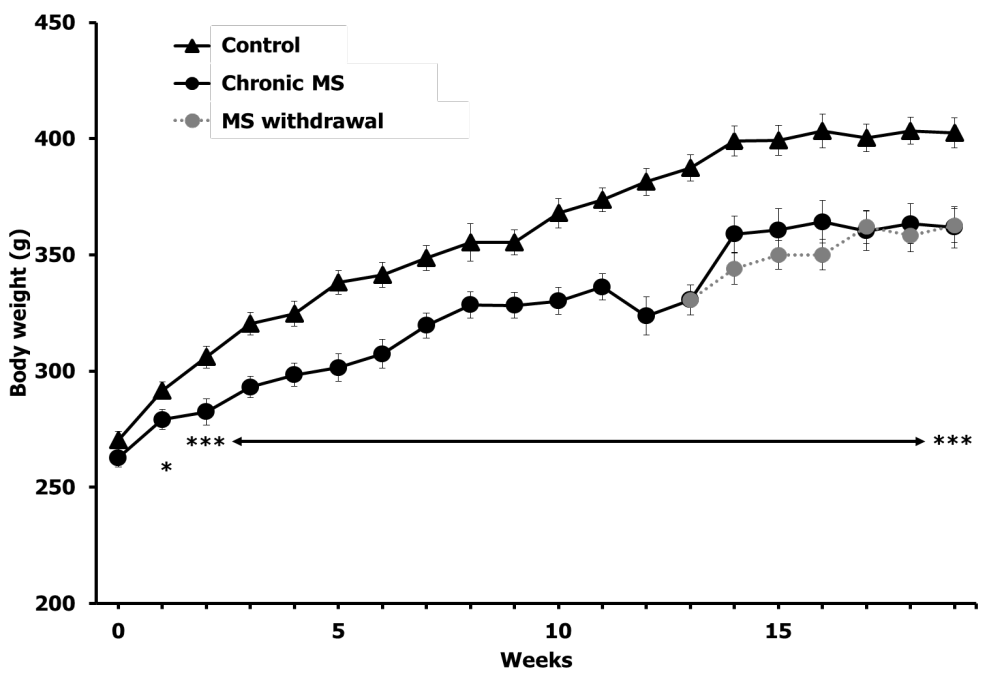

FIGURE 2. Effects of chronic treatment and withdrawal of MS alkaloid extract on body weight of rats Mean body weights measured on final day of each week in each group were selected to represent data points. Data are expressed as mean $\pm \operatorname{SEM}(\mathrm{n}=10) . *, * * * P<0.05,0.001$ respectively, significantly different from control levels. The straight horizontal line represents a continuous period of significant differences between groups with $P<0.001$

\section{EFFECTS OF CHRONIC ADMINISTRATION OF MS ALKALOID EXTRACT ON BLOOD CHEMICAL PARAMETERS}

Blood biochemical parameters of control and chronic MS alkaloid extract groups were expressed (Table 1). The mean level of non-fasting blood sugar was significantly decreased after 19-week MS alkaloid extract treatment $(p<0.05)$. Chronic group had $117.89 \pm 23.01 \mathrm{mg} \%$ whereas control group had $176.89 \pm 15.42 \mathrm{mg} \%$. From lipid analysis, the treatment significantly reduced triglyceride $(p<0.05)$ but had no effect on total cholesterol level. Triglyceride level following chronic treatment with the MS alkaloid extract $(45.89 \pm 11.01 \mathrm{mg} \%)$ was significantly lower than control level $(80.11 \pm 12.29 \mathrm{mg} \%)$. Additionally, the concentration of uric acid was significantly reduced $(p<0.05)$ from $1.99 \pm 0.68 \mathrm{mg} \%$ of control level to $1.14 \pm 0.12 \mathrm{mg} \%$ following the chronic treatment. Parameters of renal functions indicated a significant reduction of BUN $(p<0.01)$ but not creatinine. BUN level was decreased from $23.00 \pm 1.25 \mathrm{mg} \%$ (control level) to $17.78 \pm 0.72 \mathrm{mg} / \mathrm{dL}$ following the chronic treatment. Liver function parameters were found to remain unchanged mostly except only the increase of SGOT $(p<0.01)$. SGOT was significantly increased from $138.78 \pm 7.35 \mathrm{U} / \mathrm{L}$ to $190.44 \pm 19.71 \mathrm{U} / \mathrm{L}$ following the chronic treatment. 
TABLE 1. Effects of chronic treatment with MS alkaloid extract (19 weeks) on blood biochemical parameters in rats

\begin{tabular}{lcc}
\hline Parameters & Control & Chronic MS \\
\hline Non-fasting blood sugar (mg\%) & $176.89 \pm 15.42$ & $117.89 \pm 23.02^{*}$ \\
Total cholesterol (mg\%) & $58.56 \pm 2.42$ & $56.33 \pm 2.74$ \\
Triglyceride (mg\%) & $80.11 \pm 12.29$ & $45.89 \pm 11.01^{*}$ \\
Uric acid (mg\%) & $1.99 \pm 0.68$ & $1.21 \pm 0.30^{*}$ \\
BUN (mg\%) & $23.00 \pm 1.25$ & $17.78 \pm 0.72^{* *}$ \\
Creatinine (mg\%) & $0.66 \pm 0.04$ & $0.57 \pm 0.04$ \\
Total protein (g\%) & $6.71 \pm 0.18$ & $6.59 \pm 0.12$ \\
Albumin (g\%) & $2.24 \pm 0.06$ & $2.41 \pm 0.12$ \\
Total bilirubin (g\%) & $0.13 \pm 0.02$ & $0.10 \pm 0.00$ \\
Direct bilirubin (g\%) & $0.03 \pm 0.02$ & $0.01 \pm 0.01$ \\
SGOT [AST] (U/L) & $138.78 \pm 7.35$ & $190.44 \pm 19.71 *$ \\
SGPT [ALT] (U/L) & $73.00 \pm 3.34$ & $73.89 \pm 12.97$ \\
Alkaline phosphatase (U/L) & $151.44 \pm 16.23$ & $130.44 \pm 7.07$ \\
Sodium (mmole/L) & $141.44 \pm 2.13$ & $140.22 \pm 2.03$ \\
Potassium (mmole/L) & $6.89 \pm 0.27$ & $7.63 \pm 1.08$ \\
\hline
\end{tabular}

Data are expressed as mean $\pm \mathrm{SEM}(\mathrm{n}=10) . *, * * P<0.05,0.01$ respectively, significantly different from control levels

\section{EFFECTS OF CHRONIC ADMINISTRATION OF MS ALKALOID EXTRACT ON HEMATOLOGICAL PARAMETERS}

After a 19-week treatment MS alkaloid extract, a significant difference was observed only in \% monocyte $(p<0.01)$ which was decreased from about $6.44 \pm 1.70$ to $2.13 \pm 0.84 \%$ (Table 2). Values of hemoglobin, hematocrit, white blood count, \% differential neutrophil, $\%$ lymphocyte, and platelet count remained unchanged. The investigation of blood cell morphology showed the levels (control/chronic MS alkaloid treatment) of hemoglobin $(12.97 \pm 1.10 / 13.44 \pm 1.58), \%$ hematocrit $(36.79 \pm 3.51 / 30.73 \pm 4.29)$, white blood count $(3444.44 \pm$ 406.24/4955.56 \pm 922.65$), \%$ differential neutrophil (33.11 $\pm 3.87 / 41.11 \pm 4.72), \%$ lymphocyte $(58.78 \pm 4.03 / 55.89$ \pm 4.79 and platelet count $(362111 \pm 216544 / 119556$ $\pm 16656)$. The atypical lymphocyte, anisocytosis, hypochromia, microcyte, poikilocytosis, ovalocytosis of blood cells were rarely found both in chronic and control groups. No significant difference of these parameters was seen between treated and control groups.

TABLE 2. Effects of chronic treatment with MS alkaloid extract (19 weeks) on hematological parameters in rats

\begin{tabular}{lcc}
\hline Parameters & Control & Chronic MS \\
\hline Hemoglobin $(\mathrm{mg} \%)$ & $12.97 \pm 1.10$ & $13.44 \pm 1.58$ \\
Hematocrit $(\%)$ & $36.79 \pm 3.51$ & $30.73 \pm 4.29$ \\
White blood count $(\mu \mathrm{L})$ & $3444.44 \pm 406.24$ & $4955.56 \pm 922.65$ \\
\% Differential neutrophil & $33.11 \pm 3.87$ & $41.11 \pm 4.72$ \\
\% Lymphocyte & $58.78 \pm 4.03$ & $55.89 \pm 4.79$ \\
\% Monocyte & $6.44 \pm 1.70$ & $2.13 \pm 0.84^{*}$ \\
Platelet count $(\mu \mathrm{L})$ & $362111 \pm 216544$ & $119556 \pm 16656$ \\
\hline
\end{tabular}

Data are expressed as mean $\pm \operatorname{SEM}(\mathrm{n}=10) . * P<0.05$, significantly different from control levels 
EFFECTS OF MS ALKALOID EXTRACT ON FOS-LIKE IMMUNOREACTIVITY IN THE NUCLEUS ACCUMBENS

\section{AND STRIATUM}

Rat brain slices of control and treated groups showed Fos-like immunoreactivity in some brain areas. The immunoreactivity was present in selected cell nuclei. The fluorescein isothiocyanate (FITC) staining signals were similar to those observed in our previous study (Kumarnsit et al. 1999). The region of NAc was identified as the area surrounding the anterior commissure (anterior part, aca) while the STr as the area below corpus callosum. Representative brain sections containing Fos-positive signals in the NAc and STr are shown in Figure 3(A) and 3(B), respectively. High magnified images of positive signals from saline control and morphine treated animals are also shown in Figure 3(C) and 3(D). Obviously, higher density of positive signals induced by morphine was clearly seen compared to that of saline control.
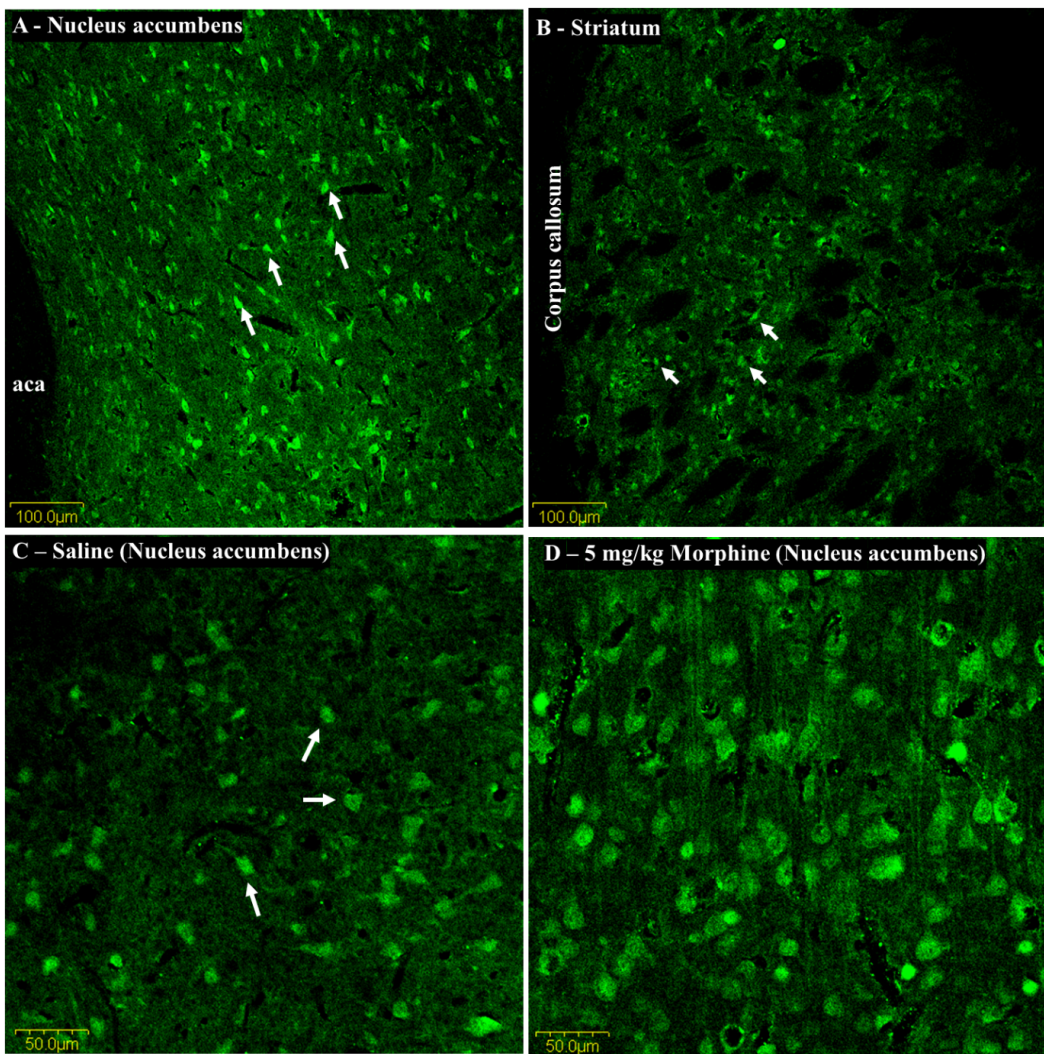

FIGURE 3. Representative brain sections showing Fos-like immunoreactivity in nucleus accumbens (A-C) and striatum (D-F) of rats treat with saline and the MS alkaloid extract ( 40 and $80 \mathrm{mg} / \mathrm{kg}$ ). All data are mean \pm SEM ( $\mathrm{n}=7$ in each group)

The brain sections of control animals that received saline showed baseline levels of Fos-like immunoreactivity. The immunoreactive cells appeared to be scattered evenly in the NAc (Figure 4(A)-4(C)). Sections from the rat that received 40 or $80 \mathrm{mg} / \mathrm{kg}$ MS alkaloid extract showed similar patterns of immunoreactivity to that of control group. Numbers of positive signals were counted and analyzed as density per $10000 \mu \mathrm{m}^{2}$ (Figure $4(\mathrm{G})$ ). The control group exhibited an average value of 16.6 Fos-like immunoreactive cells per $10000 \mu \mathrm{m}^{2}$ whereas the groups treated with 40 or $80 \mathrm{mg} / \mathrm{kg}$ MS alkaloid extract had the value of 20 and 18.8 per $10000 \mu \mathrm{m}^{2}$, respectively. The 
differences of density number among these groups were not statistically significant.

In the STr, the evenly distribution patterns of Fos-like immunoreactivity in each brain slice were also observed (Figure 4(D)-4(F)). The control group exhibited an average value of 16.5 Fos-like immunoreactive cells per 10000 $\mu \mathrm{m}^{2}$ whereas the groups treated with 40 and $80 \mathrm{mg} / \mathrm{kg}$ MS alkaloid extract had the values of 16.8 and 14.8 per $10000 \mu \mathrm{m}^{2}$, respectively (Figure 4(H)). The differences of density number between these groups were not statistically significant.

\section{Nucleus Accumbens}
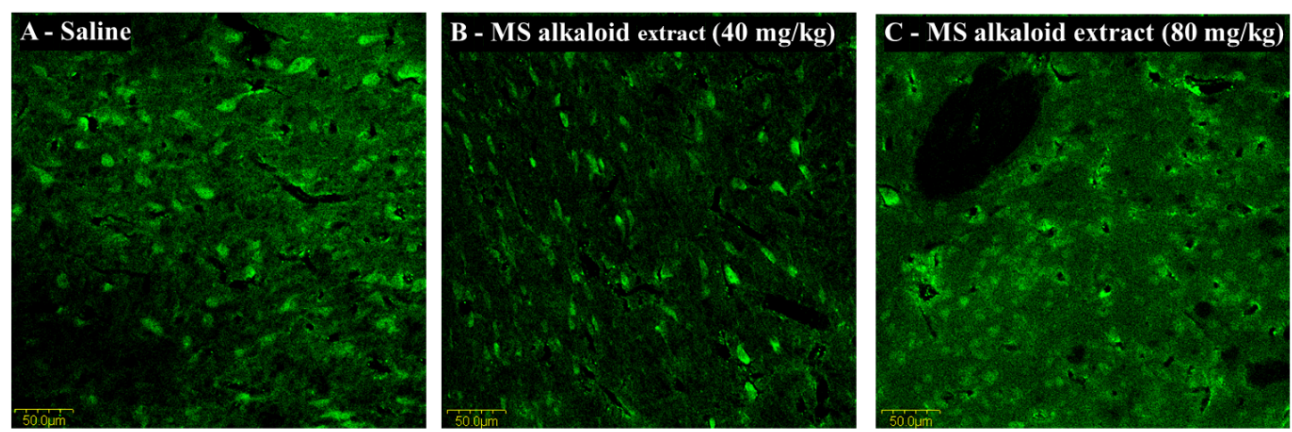

\section{Striatum}
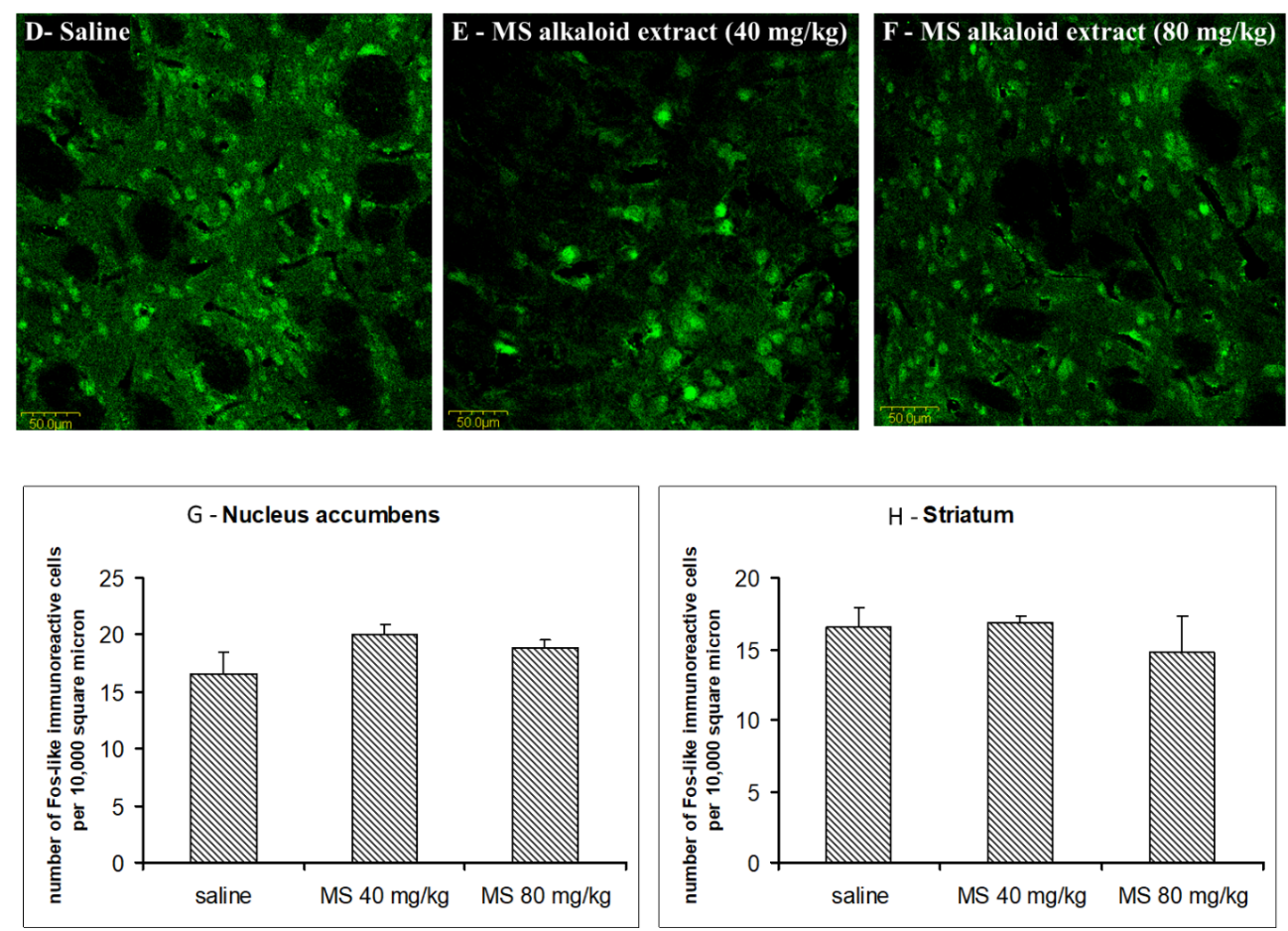

FIGURE 4. Detection of Fos-like immunoreactivity in nucleus accumbens (A) and striatum (B) of rat brain. Brain sections were incubated with anti-Fos antibodies and visualized with FITC labeled secondary antibodies using confocal microscope. Anterior commissure (aca) is a landmark of nucleus accumbens while corpus callosum is of stiatum. White arrows indicate dense nuclear staining in these brain areas. Representative brain section showing Fos-like immunoreactivity in nucleus accumbens of rats treated with saline (C) and morphine (D) 


\section{DISCUSSION}

The present study demonstrated a chronic weight-reducing effect in rats without tolerability and rebound effect. No blood test parameter reflected obvious toxicity following a 19-week administration of MS alkaloid extract. Basically, hematological parameters were used to report toxicity induced by toxin (Zhao et al. 2019) or pharmacological substances (Chakroun et al. 2016; Ito et al. 2018). The present results also demonstrated that the MS alkaloid extract did not induce Fos-like immunoreactivity in the NAc and STr. These findings suggest beneficial and nontoxic effects of kratom when whole alkaloid extract was used acutely or in a short period of treatment.

Anorectic effect of the MS alkaloid extract might be produced by multiple alkaloid constituents exhibiting multiple actions in the CNS. Apart from the major alkaloid mitragynine, various alkaloids in the MS plant have been isolated and identified (Limsuwanchote et al. 2017; Ponglux et al. 1994). Though its actions on opioid receptors were most consistently detected but other pathways such as serotonergic or noradrenergic pathways were also activated by the MS extracts such as crude alkaloid (Kumarnsit et al. 2007) or pure mitragynine (Matsumoto et al. 1996). In addition to its opioid receptor-mediated antinociception, anorectic (Kumarnsit et al. 2006) and antidepressant (Kumarnsit et al. 2007) effects were also induced by the MS alkaloid extract. Anyway, activations of either opioidergic (Nathan \& Bullmore 2009), serotonergic (Apryani et al. 2010) or noradrenergic (Ahlskog \& Hoebel 1973; Apryani et al. 2010) pathways were associated with a loss of appetite as a common action. Mitragynine had relatively lower potency when compared to morphine in terms of antinociception (Horie et al. 2005) and probably also for anorexigenic action (Leshem 1981; Wiffen et al. 2014). This might explain why tolerance effects was not observed during the negative energy balance period induced by a 19-week MS alkaloid extract treatment. In general, potent anorectic drugs that activate specific CNS pathway such as sibutramine (Gursoy et al. 2006), fluoxetine or fenfluramine (McGuirk et al. 1992) regularly have tolerance and result in hyperphagia and weight regain in compensation.

The mechanism of the MS alkaloid extract on blood sugar levels has not been consistently investigated. At least, the enhancement of glucose uptake was confirmed as one of the mechanisms that may reduce blood sugar (Purintrapiban et al. 2011). However, no longer treatment has been performed. The present data demonstrated the decreased uric acid and BUN following chronic MS alkaloid extract treatment. These findings might reflect a low breakdown of protein. Normally, they are removed from the blood by the kidney and excreted out of the body in urine or feces. The increase of uric acid is associated with gout whereas its decrease is rare and not related to serious diseases. In general, liver disease or damage can be detected with increased BUN and creatinine. The decrease of BUN and unchanged level of creatinine suggested that chronic MS alkaloid extract treatment did not induce kidney malfunction. The decreases in levels of uric acid and BUN in this study may be collectively interpreted as consequences of low food consumption during a period of MS alkaloid extract treatment. The integrity of hepatocyte was also evaluated from levels of various proteins and enzymes tested. SGOT, also known as aspartate aminotransferase, was elevated by chronic MS alkaloid extract treatment. In some pathologies such as alcoholism (Himmelstein et al. 1984) or abdominal trauma (Karaduman et al. 2003), the elevated SGOT indicates possible hepatotoxicity. However, the hepatic dysfunction was unlikely to be induced by this treatment as the rest of liver function parameters remained unchanged. The stable levels of sodium and potassium ion concentrations also confirmed that the internal environment of the body remained well-regulated.

The chronic MS alkaloid extract treatment seemed to have minimal effects on components and morphology of blood cells. The decrease of $\%$ monocytes was the only one significant change among other parameters. Previously, monocytes/macrophages were decreased in a murine model of methamphetamine consumption that might suggest immunosuppression (Harms et al. 2012). Percent (\%) of monocytes is normally increased in case of inflammation (Janardhan et al. 2006). Altogether, the decrease of \% monocytes and unchanged levels of white blood count, $\%$ differential neutrophil and \% leucocyte may suggest no infection and guarantee a normal range of components, hemopoiesis and function of the blood cells during chronic MS alkaloid extract treatment.

The two doses used in this study were effective especially in anorectic actions (Kumarnsit et al. 2006). Increasing the dose in attempt to elevate the level of Fos expression might result in overdose toxicity. Sensitivity of the immunohistochemistry method is also critical for detection and comparison of Fos expression levels. In this study, Fos-like immunoreactivities of baseline and morphine-induced levels in the NAc were clearly distinguishable. Previously, this method was used to demonstrate that pseudoephedrine, a diastereoisomer of ephedrine, induced Fos-like immunoreactivity in the NAc and STr (Kumarnsit et al. 1999). This indicates that the technique used was sensitive and suitable for this study.

The present data suggest that the MS alkaloid extract had no stimulatory effect on the NAc and STr. The former brain area is recognized as the rewarding brain center and the latter one recognized as one of dominant regions of dopaminergic pathways involved in motor function. This 
result was consistent with the findings of our previous study using the local field potential recording directly from the nucleus accumbens which indicated that the MS alkaloid extract $(80 \mathrm{mg} / \mathrm{kg}$ ) does not affect the neural signaling of the nucleus accumbens (Cheaha et al. 2017). Most of psychostimulants and opiates activate these brain areas. It means that the MS extract does not possess rewarding property. This may be the reason why this plant is usually used in combination with some other stimulant substances as cocktails in order to gain desirable levels of psychoactive effects. The use of kratom plant as a single substance does not seem to have such effect. Anyway, rewarding or addictive properties can be examined by using a variety of methods. Among those methods, selfadministration is the most straight forward and reliable technique to determine whether the substance tested has addictive effects (Doherty \& Frantz 2012; Liu et al. 2007). To examine addictive action of the MS alkaloid extract precisely, the self-administration technique is needed for confirmation. Further studies with longer administration periods are needed.

\section{CONCLUSION}

In summary, the treatment with MS alkaloid extract at $20 \mathrm{mg} / \mathrm{kg}$ for 19 weeks produced a decrease in body weight gain. An abrupt cessation after a 12-week period of MS alkaloid extract treatment was not followed by a rebound weight gain. There was also no indicator from biochemical and hematological tests that emphasized serious toxic effects of the MS alkaloid extract. Moreover, the MS alkaloid extract did not induce Fos expression in the brain rewarding center. This study suggests that MS may have beneficial effects for obesity treatment without activation on the dopaminergic brain region as observed following treatment with general psychostimulants and addictive substances.

\section{ACKNOWLEDGEMENTS}

The research of this study was funded by grants from the Thai Government Budget (Project code: SCI 49119) and the Natural Product Research Center of Excellence and Department of Physiology, Faculty of Science, Prince of Songkla University, Hatyai, Songkhla 90112, Thailand. The manuscript was proofread by Miss Nuntica (Rose) Tanasugarn, a former English teacher for the Japanese government (Japan Exchange and Teaching Programme).

\section{REFERENCES}

Ahlskog, J.E. \& Hoebel, B.G. 1973. Overeating and obesity from damage to a noradrenergic system in the brain. Science 182: $166-169$
Ahrold, T.K. \& Meston, C.M. 2009. Effects of SNS activation on SSRI-induced sexual side effects differ by SSRI. Journal of Sex \& Marital Therapy 35(4): 311-319.

Apryani, E., Taufik Hidayat, M., Moklas, M.A.A., Fakurazi, S. \& Farah Idayu, N. 2010. Effects of mitragynine from Mitragyna speciosa Korth leaves on working memory. Journal of Ethnopharmacology 129(3): 357-360.

Bitsch, M. \& Skrumsager, B.K. 1987. Femoxetine in the treatment of obese patients in general practice. A randomized group comparative study with placebo. International Journal of Obesity 11(2): 183-190.

Capaldi, V.F. \& Carr, R.B. 2010. Citalopram-induced hallucinations and delusions in a young adult. General Hospital Psychiatry 32(6): 648.e1-648.e3.

Chakroun, S., Ezzi, L., Grissa, I., Kerkeni, E., Neffati, F., Bhouri, R., Sallem, A., Najjar, M.F., Hassine, M., Mehdi, M., Haouas, Z. \& Ben Cheikh, H. 2016. Hematological, biochemical, and toxicopathic effects of subchronic acetamiprid toxicity in Wistar rats. Environmental Science and Pollution Research 23(24): 25191-25199.

Cheaha, D., Reakkamnuan, C., Nukitram, J., Chittrakarn, S., Phukpattaranont, P., Keawpradub, N. \& Kumarnsit, E. 2017. Effects of alkaloid-rich extract from Mitragyna speciosa (Korth.) Havil. on naloxone-precipitated morphine withdrawal symptoms and local field potential in the nucleus accumbens of mice. Journal of Ethnopharmacology 208: 129-137.

Cheaha, D., Keawpradub, N., Sawangjaroen, K., Phukpattaranont, P. \& Kumarnsit, E. 2015. Effects of an alkaloid-rich extract from Mitragyna speciosa leaves and fluoxetine on sleep profiles, EEG spectral frequency and ethanol withdrawal symptoms in rats. Phytomedicine 22(11): 1000-1008.

Ding, W. \& Mak, R.H. 2015. Early markers of obesity-related renal injury in childhood. Pediatric Nephrology 30(1): 1-4.

Doherty, J.M. \& Frantz, K.J. 2012. Heroin self-administration and reinstatement of heroin-seeking in adolescent vs. adult male rats. Psychopharmacology 219(3): 763-773.

Edge, J.P. \& Gold, S.M. 2012. Drug withdrawal and hyperphagia: Lessons from tobacco and other drugs. Current Pharmaceutical Design 17(12): 1173-1179.

Farah Idayu, N., Taufik Hidayat, M., Moklas, M.A.M., Sharida, F., Nurul Raudzah, A.R., Shamima, A.R. \& Apryani, E. 2011. Antidepressant-like effect of mitragynine isolated from Mitragyna speciosa Korth in mice model of depression. Phytomedicine 18(5): 402-407.

Gallagher, E.J., LeRoith, D. \& Karnieli, E. 2010. Insulin resistance in obesity as the underlying cause for the metabolic syndrome. Mount Sinai Journal of Medicine: A Journal of Translational and Personalized Medicine 77(5): 511-523.

Graybiel, A.M., Moratalla, R. \& Robertson, H.A. 1990. Amphetamine and cocaine induce drug-specific activation of the c-fos gene in striosome-matrix compartments and limbic subdivisions of the striatum. Proceedings of the National Academy of Sciences of the United States of America 87(17). pp. 6912-6916.

Gursoy, A., Erdogan, M.F., Cin, M.O., Cesur, M. \& Baskal, N. 2006. Comparison of orlistat and sibutramine in an obesity 
management program: Efficacy compliance, and weight regain after noncompliance. Eating and Weight Disorders 11(4): e127-e132.

Harizal, S.N., Mansor, S.M., Hasnan, J., Tharakan, J.K.J. \& Abdullah, J. 2010. Acute toxicity study of the standardized methanolic extract of Mitragyna speciosa Korth in Rodent. Journal of Ethnopharmacology 131(2): 404-409.

Harms, R., Morsey, B., Boyer, C.W., Fox, H.S. \& Sarvetnick, N. 2012. Methamphetamine administration targets multiple immune subsets and induces phenotypic alterations suggestive of immunosuppression. PLoS ONE 7(12): e49897.

Harun, N., Hassan, Z., Navaratnam, V., Mansor, S.M. \& Shoaib, M. 2015. Discriminative stimulus properties of mitragynine (kratom) in rats. Psychopharmacology 232(13): 2227-2238.

Himmelstein, D.U., Woolhandler, S.J. \& Adler, R.D. 1984. Elevated SGOT/SGPT ratio in alcoholic patients with acetaminophen hepatotoxicity. The American Journal of Gastroenterology 79(9): 718-720.

Horie, S., Koyama, F., Takayama, H., Ishikawa, H., Aimi, N., Ponglux, D., Matsumoto, K. \& Murayama, T. 2005. Indole alkaloids of a Thai medicinal herb, Mitragyna speciosa, that has opioid agonistic effect in guinea-pig ileum. Planta Medica 71(3): 231-236.

Hyman, S.E. 1996. Addiction to cocaine and amphetamine. Neuron 16(5): 901-904.

Ito, Y., Kobuchi, S., Shimizu, R. \& Katsuyama, Y. 2018. Pharmacokinetic and toxicodynamic evaluation of oxaliplatininduced neuropathy and hematological toxicity in rats. Cancer Chemotherapy and Pharmacology 81(1): 155-161.

Janardhan, K.S., Sandhu, S.K. \& Singh, B. 2006. Neutrophil depletion inhibits early and late monocyte/macrophage increase in lung inflammation. Frontiers in Bioscience 11: 1569-1576.

Jansen, K.L.R. \& Prast, C.J. 1988. Psychoactive properties of mitragynine (Kratom). Journal of Psychoactive Drugs 20(4): 455-457.

Karaduman, D., Sarioglu-Buke, A., Kilic, I. \& Gurses, E. 2003. The role of elevated liver transaminase levels in children with blunt abdominal trauma. Injury 34(4): 249-252.

Kumarnsit, E., Vongvatcharanon, U., Keawpradub, N. \& Intasaro, P. 2007. Fos-like immunoreactivity in rat dorsal raphe nuclei induced by alkaloid extract of Mitragyna speciosa. Neuroscience Letters 416(2): 128-132.

Kumarnsit, E., Keawpradub, N. \& Nuankaew, W. 2006. Acute and long-term effects of alkaloid extract of Mitragyna speciosa on food and water intake and body weight in rats. Fitoterapia 77(5): 339-345.

Kumarnsit, E., Harnyuttanakorn, P., Meksuriyen, D., Govitrapong, P., Baldwin, B.A., Kotchabhakdi, N. \& Casalotti, S.O. 1999. Pseudoephedrine, a sympathomimetic agent, induces Fos-like immunoreactivity in rat nucleus accumbens and striatum. Neuropharmacology 38(9): 1381-1387.

Leshem, M. 1981. Morphine-induced anorexia in lateral hypothalamic rats. Psychopharmacology 75(1): 48-53.

Limsuwanchote, S., Putalun, W., Keawpradub, N., Tanaka, H., Morimoto, S. \& Wungsintaweekul, J. 2017. Anti-mitragynine monoclonal antibody-based ELISA for determination of alkaloids in the kratom cocktail. Forensic Toxicology 35(1): 167-172.

Liu, Y., Morgan, D. \& Roberts, D.C.S. 2007. Cross-sensitization of the reinforcing effects of cocaine and amphetamine in rats. Psychopharmacology 195(3): 369-375.

Matsumoto, K., Horie, S., Ishikawa, H., Takayama, H., Aimi, N., Ponglux, D. \& Watanabe, K. 2004. Antinociceptive effect of 7-hydroxymitragynine in mice: Discovery of an orally active opioid analgesic from the Thai medicinal herb Mitragyna speciosa. Life Sciences 74(17): 2143-2155.

Matsumoto, K., Mizowaki, M., Suchitra, T., Murakami, Y., Takayama, H., Sakai, S.I., Aimi, N. \& Watanabe, H. 1996. Central antinociceptive effects of mitragynine in mice: Contribution of descending noradrenergic and serotonergic systems. European Journal of Pharmacology 317(1): 75-81

McElroy, S.L., Hudson, J.I., Malhotra, S., Welge, J.A., Nelson, E.B. \& Keck, P.E. 2003. Citalopram in the treatment of bingeeating disorder: A placebo-controlled trial. The Journal of Clinical Psychiatry 64(7): 807-813.

McGuirk, J., Muscat, R. \& Willner, P. 1992. Effects of chronically administered fluoxetine and fenfluramine on food intake, body weight and the behavioural satiety sequence. Psychopharmacology 106(3): 401-407.

Nathan, P.J. \& Bullmore, E.T. 2009. From taste hedonics to motivational drive: Central-opioid receptors and binge-eating behaviour. The International Journal of Neuropsychopharmacology 12: 995-1008.

Pifl, C., Drobny, H., Reither, H., Hornykiewicz, O. \& Singer, E.A. 1995. Mechanism of the dopamine-releasing actions of amphetamine and cocaine: Plasmalemmal dopamine transporter versus vesicular monoamine transporter. Molecular Pharmacology 47(2): 368-373.

Ponglux, D., Wongseripipatana, S., Takayama, H., Kikuchi, M., Kurihara, M., Kitajima, M., Aimi, N. \& Sakai, S. 1994. A new indole alkaloid, $7 \alpha$-hydroxy- $7 \mathrm{H}$-mitragynine, from Mitragyna speciosa in Thailand. Planta Medica 60(6): 580-581.

Purintrapiban, J., Keawpradub, N., Kansenalak, S., Chittrakarn, S., Janchawee, B. \& Sawangjaroen, K. 2011. Study on glucose transport in muscle cells by extracts from Mitragyna speciosa (Korth) and mitragynine. Natural Product Research 25(15): 1379-1387.

Ruksee, N., Tongjaroenbuangam, W., Casalotti, S.O. \& Govitrapong, P. 2008. Amphetamine and pseudoephedrine cross-tolerance measured by c-Fos protein expression in brains of chronically treated rats. BMC Neuroscience 9: 1-8.

Sabetghadam, A., Ramanathan, S., Sasidharan, S. \& Mansor, S.M. 2013. Subchronic exposure to mitragynine, the principal alkaloid of Mitragyna speciosa, in rats. Journal of Ethnopharmacology 146(3): 815-823.

Seiden, L.S., Sabol, K.E. \& Ricaurte, G.A. 1993. Amphetamine: Effects on catecholamine systems and behavior. Annual Review of Pharmacology and Toxicology 33: 639-677.

Sharp, T., Zetterström, T., Ljungberg, T. \& Ungerstedt, U. 1987. A direct comparison of amphetamine-induced behaviours and regional brain dopamine release in the rat using intracerebral dialysis. Brain Research 401(2): 322-330 
Sufka, K.J., Loria, M.J., Lewellyn, K., Zjawiony, J.K., Ali, Z., Abe, N. \& Khan, I.A. 2014. The effect of Salvia divinorum and Mitragyna speciosa extracts, fraction and major constituents on place aversion and place preference in rats. Journal of Ethnopharmacology 151(1): 361-364.

Sussman, N., Ginsberg, D.L. \& Bikoff, J. 2001. Effects of nefazodone on body weight: A pooled analysis of selective serotonin reuptake inhibitor- and imipramine-controlled trials. Journal of Clinical Psychiatry 62(4): 256-260.

Takayama, H., Ishikawa, H., Kurihara, M., Kitajima, M., Aimi, N., Ponglux, D., Koyama, F., Matsumoto, K., Moriyama, T., Yamamoto, L.T., Watanabe, K., Murayama, T. \& Horie, S. 2002. Studies on the synthesis and opioid agonistic activities of mitragynine-related indole alkaloids: Discovery of opioid agonists structurally different from other opioid ligands. Journal of Medicinal Chemistry 45(9): 1949-1956.

Takayama, K., Suzuki, T. \& Miura, M. 1994. The comparison of effects of various anesthetics on expression of Fos protein in the rat brain. Neuroscience Letters 176(1): 59-62.

Wiffen, P.J., Derry, S. \& Moore, R.A. 2014. Impact of morphine, fentanyl, oxycodone or codeine on patient consciousness, appetite and thirst when used to treat cancer pain. Cochrane Database of Systematic Reviews 5(CD011056): 1-111.

Yusoff, N.H.M., Suhaimi, F.W., Vadivelu, R.K., Hassan, Z., Rümler, A., Rotter, A., Amato, D., Dringenberg, H.C., Mansor, S.M., Navaratnam, V. \& Müller, C.P. 2016. Abuse potential and adverse cognitive effects of mitragynine (kratom). Addiction Biology 21(1): 98-110.

Zhao, Q., Yang, Z.S., Cao, S.J., Chang, Y.F., Cao, Y.Q., Li, J.B., Yao, Z.X., Wen, Y.P., Huang, X.B., Wu, R., Yan, Q.G., Huang, Y., Ma, X.P., Han, X.F. \& Wu, Y. 2019. Acute oral toxicity test and assessment of combined toxicity of cadmium and aflatoxin B1 in kunming mice. Food and Chemical Toxicology 131(2019): 110577.

Ekkasit Kumarnsit

Division of Health and Applied Sciences

Faculty of Science

Prince of Songkla University, Hatyai

Songkhla 90112

Thailand
Ekkasit Kumarnsi \& Dania Cheaha* Biosignal Research Center for Health

Faculty of Science

Prince of Songkla University, Hatyai

Songkhla 90112

Thailand

Ekkasit Kumarnsit

The Natural Product Research Center of Excellence

Faculty of Science

Prince of Songkla University, Hatyai

Songkhla 90112

Thailand

Niwat Keawpradub, Narumon Sengnon \& Juraithip Wungsintaweekul

Department of Pharmacognosy and Pharmaceutical Botany

Faculty of Pharmaceutical Sciences

Prince of Songkla University, Hatyai

Songkhla 90112

Thailand

Dania Cheaha*

Division of Biological Science

Faculty of Science

Prince of Songkla University, Hatyai

Songkhla 90112

Thailand

*Corresponding author; email: dania.c@psu.ac.th

Received: 24 April 2019

Accepted: 18 August 2020 